\title{
Aspek Klinis dan Diagnosis Kandidiasis Vulvovaginal
}

\author{
Nora Harminarti*
}

\begin{abstract}
Candidiasis vulvovaginal is an infection of the vaginal and vulva area caused by yeast Candida. The most causative species is Candida albicans. This fungus is commensal in the vagina but it can become a pathogen, causing the infection under certain conditions. Several conditions can be risk factors for this infection. Women are mostly getting infections, especially of productive age. Complaints experienced cause disturbances in the form of itching accompanied by abnormal vaginal discharge. The clinician can make diagnostics based on anamnesis, clinical and microscopic examination. This paper provides information about the causes, risk factors, clinical symptoms, and laboratory testing.
\end{abstract}

Keywords: vaginal discharge, yeast, infection

Kandidiasis vulvovaginal (KVV) merupakan inflamasi pada daerah vagina dan vulva yang disebabkan oleh terutama spesies Candida albicans atau salah satu dari spesies non Candida albicans : Candida glabrata, Candida tropicalis, Candida parapsilosis dan Candida krusei. ${ }^{1}$ Wanita biasanya dapat mengalami infeksi sedikitnya satu episode kandidiasis vulvovaginal selama hidupnya sekitar $75-80 \%$ dan diperkirakan 40-50\% mengalami infeksi ulangan. Faktor predisposisi seperti fluktuasi hormon kehamilan, fase luteal siklus menstruasi, penggunaan kontrasepsi oral dan terapi penggantian hormon. ${ }^{2}$

Genetik, biologi, perilaku, penggunaan antibiotika, kehamilan (30-40\%) dan diabetes tidak terkontrol berhubungan dengan meningkatnya angka insiden kolonisasi Candida pada vagina. Beberapa laporan menyebutkan frekuensi hubungan seksual, sering melahirkan juga mempengaruhi insiden penyakit ini. ${ }^{3}$ Faktor lain yang diduga sebagai predisposisi adalah pemakaian pakaian ketat

Penulis untuk korespondensi: Fakultas Kedokteran Universitas Andalas, Padang, Sumatera Barat, Indonesia. Email : noraharminarti@med.unand.ac.id dan pakaian dalam berbahan sintetis. Beberapa laporan menyatakan terdapat hubungan KVV dengan peningkatan transmisi dan penyebaran HIV.,, 5

Secara laboratoris, seorang wanita dikatakan memiliki gejala klinis kandidiasis vulvovaginal bila hitung jamur vagina lebih dari $103 \mathrm{CFU} / \mathrm{ml}$ dari cairan vagina. ${ }^{3}$ Gejala secara umum adalah gatal, rasa terbakar, rasa sakit, vaginal discharge abnormal dan dispareunia. ${ }^{6,7}$ Tujuan penulisan ini adalah membahas penyebab, faktor risiko, gejala klinis dan penegakan diagnosis kandidiasis vulvovaginal.

\section{Penyebab}

Lapisan vagina terbentuk dari epitel nonkeratinized stratified squamous dengan cairan servikovaginal yang berfungsi sebagai pelumas sehingga dapat menjadi penghalang fisik dan biokimia terhadap organisme asing yang menyerang. Pada sebagian besar vagina wanita sehat usia reproduksi juga mengandung banyak mikroorganisme seperti Lactobacillus spp dan anaerob lain seperti Gardnerella, Atopobium, Mobiluncus, Prevotella, Streptococcus, Ureaplasma, Megasphaera dan lain lain., ${ }^{6,8}$ 
Spesies C.albicans sekitar 85-95\% diidentifikasi sebagai mayoritas penyebab KVV namun telah dilaporkan peningkatan frekuensi spesies non Candida albicans lainnya seperti C.glabrata 3,4-20\%, C.tropicalis $17,9 \%$, C. parapsilosis $10,2 \%$ dan C. krusei $5,8 \%$. Munculnya spesies Candida lainnya ini diduga oleh karena meluasnya penggunaan obat yang dijual bebas, penggunaan jangka panjang azol dan penggunaan obat antijamur yang singkat. ${ }^{1,10}$

\section{Faktor Risiko}

Flora vagina dan mikroba sekitarnya memiliki hubungan yang sangat dinamis yaitu terdapat keseimbangan antara kolonisasi Candida dan lingkungan sekitar vagina. Kondisi ini dapat terganggu oleh perubahan fisiologis atau nonfisiologis sehingga membentuk daerah kolonisasi yang menguntungkan untuk perkembangan jamur. Wanita sehat bisa saja memiliki faktor risiko yang dapat mengganggu lingkungan vagina sehingga bisa menyebabkan KVV. Faktor risiko terkait host seperti kehamilan, terapi penggantian hormon, diabetes mellitus yang tidak terkontrol, imunosupresi, penggunaan antibiotika dan glukokortikoid serta predisposisi genetik. Faktor risiko perilaku lain seperti penggunaan kontrasepsi oral, higien dan pakaian. ${ }^{1,11}$

Infeksi sering terjadi pada wanita selama masa reproduksi dan menimbulkan masalah khusus selama kehamilan. Prevalensi pada wanita hamil sekitar $30 \%$, terutama pada trimester kedua dan ketiga dengan gejala simptomatik maupun asimptomatik. Peningkatan risiko pada kehamilan disebabkan oleh faktor yang berhubungan dengan kehamilan, seperti perubahan imunologis, peningkatan kadar hormon reproduksi dan peningkatan produksi glikogen. ${ }^{11}$

Pengaruh hormonal dapat dilihat dari jarangnya angka kejadian pada pra-pubertas dan pasca menopause, kecuali pada wanita yang menggunakan hormone replacement therapy (HRT). ${ }^{1,7}$
Penggunaan pil kontrasepsi oral juga dapat menjadi faktor risiko. Beberapa penelitian melaporkan efek hormonal pada kehamilan sama dengan pemakaian pil kontrasepsi oral, terutama yang mengandung dosis hormonal tinggi. Penggunaan pil kontrasepsi oral dapat meningkatkan glikogen vagina sehingga terjadi peningkatan ketersediaan nutrisi karbohidrat yang mendukung pertumbuhan Candida serta dapat meningkatkan adhesi Candida ke epitel vagina. ${ }^{1,7}$

Kondisi imunosupresif seperti infeksi Human Immunodeficiency Virus (HIV), kemoterapi kanker, terapi glukokortikoid, transplantasi organ, kanker, diabetes melitus, tuberkulosis dan penyakit kronis lainnya dapat menjadi faktor risiko. ${ }^{1}$

Prevalensi KVV pada penderita diabetes melitus lebih tinggi dibandingkan yang bukan. Insiden pada wanita diabetes berkisar antara 32$67,5 \%$ dibandingkan dengan yang bukan sekitar $11-23 \%$. Perkembangan kolonisasi Candida juga ditemukan lebih tinggi pada pasien diabetes. ${ }^{1,12}$

Penggunaan antibiotika (vagina atau sistemik) dapat menjadi faktor risiko. Penelitian menunjukkan peningkatan angka kejadian KVV pada wanita yang telah minum antibiotika dibandingkan yang tidak. Penyebab yang paling sering adalah antibiotika spektrum luas seperti tetrasiklin, ampisilin, dan sefalosporin. Antibiotika menyebabkan penipisan mikroflora bakteri vagina sebagai mekanisme pertahanan vagina yang dominan terhadap Candida. ${ }^{12,13}$

Faktor lain yang potensial adalah pakaian ketat, dimana terjadi peningkatan kelembapan perineum dan suhu yang dapat berkontribusi terhadap proliferasi Candida. Pakaian dalam sintetis dapat menyebabkan reaksi alergi dan hipersensitivitas lokal serta mengubah lingkungan vagina. ${ }^{1,4}$

Perilaku higiene wanita yang dapat memicu hipersensitivitas lokal atau reaksi alergi seperti penggunaan pantyliner dan cairan pembersih vagina. Cairan pembersih vagina tidak hanya memasukkan zat eksogen yang dapat menyebabkan reaksi alergi dan perubahan $\mathrm{pH}$, tetapi juga mendorong pembersihan mekanis dari bakteri komensal yang mempengaruhi keseimbangan ekologi rongga vagina. ${ }^{1,4}$ 


\section{Gejala Klinis dan Penegakan Diagnosis}

Kandidiasis vulvovaginal biasanya memiliki gejala pada vagina yang berhubungan dengan peradangan yaitu gatal diikuti dengan rasa terbakar, kemerahan, keputihan berupa sekret kental seperti keju, berwarna putih kekuningan, disuria, dispareunia, nyeri vagina dan vagina kering. ${ }^{6,710,14}$ Semua spesies Candida menghasilkan gejala infeksi vulvovaginal yang serupa meskipun presentasi spesies non Candida albicans seringkali lebih ringan atau bahkan asimtomatik. Kasus berulang sering muncul dengan gejala gatal lebih dominan dan sekret lebih jarang. Pada vulva dapat terjadi eritema dengan fisura yang sering terlokalisasi pada tepi mukosa introitus vagina dan dapat meluas mengenai labia mayora disertai gatal dan kemerahan. ${ }^{5}$

Candida albicans merupakan spesies penyebab yang sering ditemukan. Diagnosis kandidiasis vulvovaginal dapat dilakukan berdasarkan anamnesis, gejala klinis, diikuti dengan pemeriksaan mikroskopis menggunakan $\mathrm{KOH} 10 \%$. Pada pemeriksaan dapat ditemukan pseudohifa, sel-sel bertunas (budding yeast cells) berbentuk oval. Diagnosis juga dapat ditegakkan dengan melakukan kultur. Hasil kultur berupa koloni berwarna putih, permukaan licin, menonjol disertai bau khas (yeast odor). 5,7,16

Berikut ini dapat dilihat salah satu gambaran spesies C.albicans sebagai penyebab terbanyak dari kandidiasis vulvovaginal :

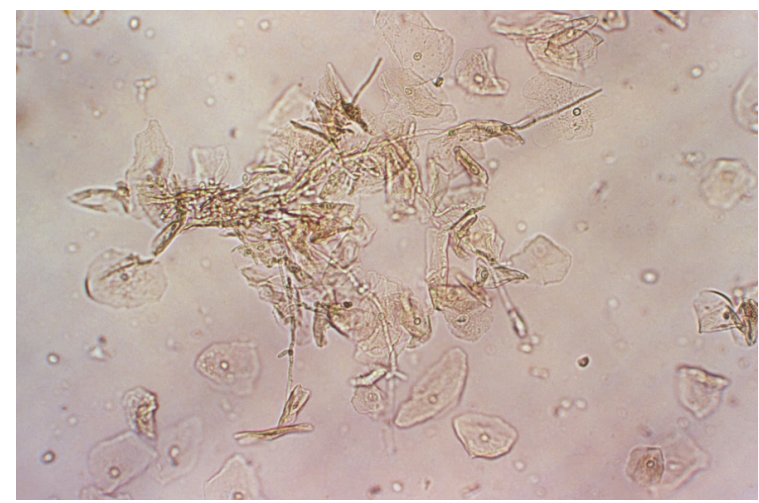

Gambar 1. C. albicans pada pulasan sediaan basah dari spesimen sekret vagina pasien candidiasis vagina. ${ }^{17}$

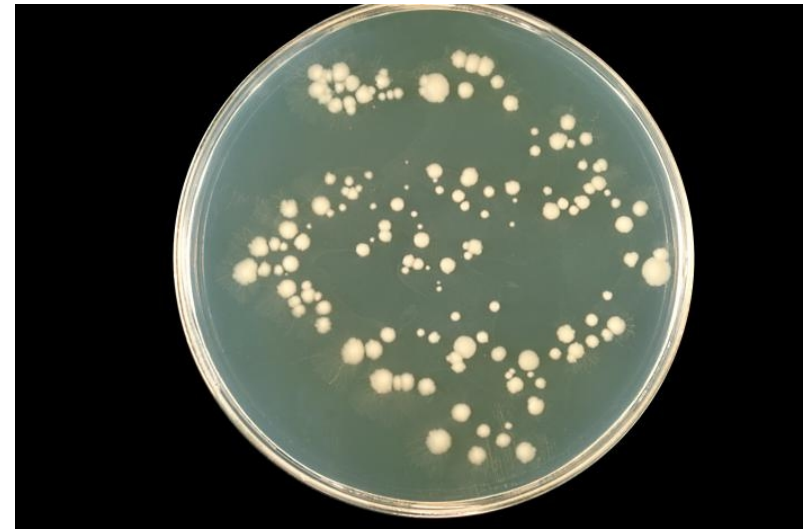

Gambar 2. Kultur C.albicans ${ }^{17}$

\section{PENUTUP}

Kandidiasis vulvovaginal merupakan suatu infeksi daerah vulvovaginal yang disebabkan oleh spesies golongan Candida dengan penyebab terbanyak adalah C.albicans. Gejala klinis yang khas berupa gatal, keputihan, rasa terbakar, edema, eritema vulva dan vagina, disuria, dispareunia dan nyeri vagina. Pemeriksaan laboratorium secara mikroskopis menggunakan $\mathrm{KOH} 10 \%$ pada sekret vagina dan kultur.

\section{DAFTAR PUSTAKA}

1. Gonçalves B, Ferreira C, Alves CT, Henriques M, Azeredo J, Silva S. Vulvovaginal candidiasis: Epidemiology, microbiology and risk factors. Crit Rev Microbiol. 2016;42(6):905-27.

2. Rosati D, Bruno M, Jaeger M, Ten Oever J, Netea MG. Recurrent vulvovaginal candidiasis: An immunological perspective. Microorganisms. 2020;8(2):1-14.

3. Chatzivasileiou P, Vyzantiadis TA. Vaginal yeast colonisation: From a potential harmless condition to clinical implications and management approaches-A literature review. Mycoses. 2019;62(8):638-50.

4. Zeng X, Zhang Y, Zhang T, Xue Y, Xu H, An R. Risk factors of vulvovaginal candidiasis among women of reproductive age in Xi'an: A crosssectional study. Biomed Res Int. 2018;2018.

5. M Lema V. Recurrent vulvo-caginal candidiasis: Diagnostic and management challenges in a developing country context. Obstet Gynecol Int J. 2017;7(5). 
6. ACOG. Clinical management guidelines for obstetrician - gynecologists. Obstet Gynecol. 2020;135(1):e1-17.

7. Rao VL, Mahmood T. Vaginal discharge. Obstet Gynaecol Reprod Med [Internet]. 2020;30(1):11-8. Available from: https://doi.org/10.1016/j.ogrm.2019.10.004

8. Amabebe E, Anumba DOC. The vaginal microenvironment: The physiologic role of Lactobacilli. Front Med. 2018;5(JUN):1-11.

9. Miller EA, Beasley DAE, Dunn RR, Archie EA. Lactobacilli dominance and vaginal $\mathrm{pH}$ : Why is the human vaginal microbiome unique? Front Microbiol. 2016;7(DEC):113.

10. Venugopal D, Husain K, Mustafa SA, Sabeen S. Epidemiology, risk factors and antimicrobial profile of vulvovaginal candidiasis (VVC): A study among women in the central region of Saudi Arabia. J Med Mycol [Internet]. 2020;1-4. Available from: https://doi.org/10.1016/j.mycmed.2020.101 $\underline{049}$

11. Aguin TJ, Sobel JD. Vulvovaginal candidiasis in pregnancy. Curr Infect Dis Rep. 2015;17(6):15-20.
12. Cauchie M, Desmet S, Lagrou K. Candida and its dual lifestyle as a commensal and a pathogen. Res Microbiol [Internet]. 2017;168(9-10):80210. Available from: https://doi.org/10.1016/j.resmic.2017.02.005

13. Shukla A, Sobel JD. Vulvovaginitis caused by candida species following antibiotic exposure. Curr Infect Dis Rep. 2019;21(11).

14. Yano J, Sobel JD, Nyirjesy P, Sobel R, Williams VL, Yu Q, et al. Current patient perspectives of vulvovaginal candidiasis: Incidence, symptoms, management and posttreatment outcomes. BMC Womens Health. 2019;19(1):1-9.

15. Cymerman RM, Kaplan Hoffmann R, Rouhani Schaffer P, Pomeranz MK. Vulvar infections: beyond sexually transmitted infections. Int $\mathrm{J}$ Dermatol. 2017;56(4):361-9.

16. Paladine HL, Desai UA. Vaginitis : Diagnosis and treatment. am fam physician. 2018;97(5):321-30.

17. CDC. Details - Public Health Image Library(PHIL) [Internet]. CDC Organization. 2020. (accsessed on : 03 Februari 2021). Available from: https://phil.cdc.gov/Details.aspx?pid=3063\%0A https://phil.cdc.gov/Details.aspx?pid=18758 